\title{
An Analysis of Assessment of Financial Distress in Textile Sector of Pakistan (2012-2018)
}

\author{
Talha Majeed Khan \\ Faculty of Management Studies, University of Central Punjab, Lahore \\ Qais Aslam (PhD) \\ Faculty of Management Studies, University of Central Punjab, Lahore \\ Faisal Mustafa (PhD) \\ Dean, Faculty of Management Studies, University of Central Punjab, Lahore
}

\begin{abstract}
As business expand in modern global economy, cutthroat competition also becomes a reality. It becomes more important for businesses not only to diversify but also to break through with their respective products on different markets through cost cutting techniques and technologies. For survival and carrying on business activities, an organization should have to manage their finances on priority matters that need utmost care and attention. Therefore, company's financial health and position can be monitored through their financial statement. Broad based expansion in private sector loans during Jul-Feb FY2018 makes financing requirement increased for working capital due to increase in input prices of cotton and coal. Large amount of loans are a burden on textile firms. More use of loans may results into the problem of financial distress that may lead to future bankruptcy. The objective of the study is to analyze the financial distress prediction in textile sector of Pakistan during the period 2012 to 2018. Dependent variable is financial distress prediction and independent variables are WC/TD, RE/TA, EBT/Equity, $\mathrm{CF} / \mathrm{TD}, \mathrm{S} / \mathrm{TA}$, interest rates, exchange rates, cotton prices and export prices. Researcher took secondary data of 120 textile-listed firms for the period of seven years from 2012 to 2018 derived from annual reports.Regression analysis, ANOVA and correlation were performed to check whether independent variables have significant relation with financial distress prediction. Results revealed that WC/TD, interest rates, cotton prices and export prices were found significant.RE/TA, EBT/Equity, CF/TD, and S/TA and exchanges rates have negative and insignificant relation with financial distress prediction.
\end{abstract}

Keywords: Financial distress, bankruptcy prediction, Fulmer model, Pakistan Stock Exchange, Financial ratios, Macroeconomic indicators

DOI: $10.7176 / \mathrm{EJBM} / 11-19-01$

Publication date:July $31^{\text {st }} 2019$

\section{Introduction 1}

As business expand in modern global economy, cutthroat competition also becomes a reality. It becomes more important for businesses not only to diversify but also to break through with their respective products on different markets through cost cutting techniques and technologies. For survival and carrying on business activities an organization should have to manage their finances on priority matters which need utmost care and attention (Dr. M. Velavan, M., Pavithra, Pavisathya, \&Padmaja, 2018). Therefore, company's financial health and position can be monitored through their financial statement that tells how good company's operational competence and strong financial health is (Dr. M. Velavan, M. Mumtha, Pavithra, Pavisathya, \&Padmaja, 2018). Financial distress comprises of numerous situations where a company has to face some form of financial difficulty. Problems of bankruptcy can be found in both developing and developed economies. However, mostly its presence is in developing economies (Geng, Bose \& Chen, 2015). It has numerous definitions such as failure, default, insolvency and bankruptcy (Geng, Bose \& Chen, 2015).

According to Altman (1993) "the realized rate of return on invested capital, with allowances for risk consideration, is significantly and continually lower than prevailing rates of similar investments." In general, this is an economic sense and has no relation with the lack of continuity of firm. Due to insolvency negative performance has recorded that creates liquidity problem and shows negative net worth. Last but not the least, default is a situation where any firm unable to fulfill their obligations or violates the condition of agreement with their creditor that makes them accountable at court of law.

Bankruptcy prediction is one of the pivotal problems that have been extensively studied in accounting and finance literature. Importance of corporate governance is increasing due to the increasing importance of predicting financial distress that causes severe effects on operations of firm, its environment and whole economy (Arnold, 2007). It is important to underline the indicators of distress, as to what are the reasons behind them and what possible solutions available before they reach at crisis stage, as many managers try to focus only on following year, at least in the short run (Harlan \& Marjorie, 2002). As a result, an early warning system is essential for a company 
to monitor and measure its financial position and health because strong companies today have chances to become weak tomorrow and companies that are already weak today might have chance to survive.

Fulmer, Moon, James, Gavin, Erwin, and Michael (1984),presented a comprehensive model that came to be known as H-score in scientific literature, consists of nine variables. The Fulmer model started from a set of forty ratios based on sixty companies consisting of thirty distress and thirty non-distress firms with nine ratios included in final model. Fulmer model categorize d companies correctly one year prior to failure at an accuracy rate of 98 percent and the ratio becomes 81 percent for more than one year prior to bankruptcy.

Pakistan becomes fourth largest country that produces cotton, sixth largest importer of raw cotton and becomes third largest consumer of cotton in world. Textile industry accounts for $8.5 \%$ of GDP and around $62 \%$ of total export earning of Pakistan. Sector administer nearly one fourth of industrial value added and provides employment to about $40 \%$ of industrial labor force. The economic situation of the country is becoming unsustainable due to high trade deficit and mounting debt payments posing national security risk. Since 2008 until 2017, Pakistan has added US\$ 43 Billion of debt. Compared to regional competitor countries, Pakistan's Gross Domestic Saving Rate (at 12\%) is low (Government of Pakistan, 2017-2018).

In Textile Spinning there are eighty-one companies listed at Karachi Stock Exchange with their paid up capital and market capitalization of approximately PKR 22.3Billion and PKR 47.655 Billion. Whereas in Textile Weaving there are, thirteen companies listed with paid up capital and market capitalization of PKR 2.3 Billion and PKR 25.56 Billion. In Textile Composite there are fifty two companies listed with approximately total paid up capital and market capitalization of PKR 14.721 Billion PKR 217.806 Billion(Government of Pakistan, 2017-2018).

Pakistan textiles are facing multifaceted problems on all three international, national and textile industry specific fronts. Internationally, Pakistan's textile and clothing export growths are decreasing, whereas our regional competition is seeing a multiplying growth. In addition, world trade has started moving away from cotton products towards man-made fibers (MMF) whereas Pakistan export mix has stayed the same. Pakistan's trade performance is the outcome of diminishing export competitiveness and the country has lost 1.5 percent annually in export market share and its exports dropped by 20.2 percent in 2013-2015.

\subsection{Problem Statement 2}

Like other countries of the world, Pakistan also lost their major export share in international market. Comparing to those countries, economy of Pakistan rely more on textile industry that makes this situation more pivotal and have a decisive impact on economy. Pakistan textile sector have severe challenges from China, India and other Asian countries who from last many years established a solid base for their value added textile. Regardless of investing Billions of dollars in upgrading textile technology our textile sector is still facing a critical situation in global competition. Due to severe competition with India and Bangladesh, many units have stopped their production. Power loom sectorial problems were developing due to weak management, insufficient technology, shortage of quality yarn. There are 9084 looms installed in cotton textile mills and only 6384 are working. Furthermore, production data of cloth mills sector is reported, likewise production data of non-mill data is only estimated, as there is no data available about them. Cotton cloth production somewhat increased by 0.03 percent but remained inactive, at the same time there is a 0.80 percent decrease is recorded in exports of their quantity, whereas 0.04 percent increase in value term (Government of Pakistan, 2017-2018).

During July-February fiscal year, 2018 there was an immense increase in private sector loans especially in manufacturing sector that received a share of almost 59.8 percent or (PKR 206.3 Billion). Textile share was 35.8 percent (PKR 123.5 Billion), therefore during fiscal year 2017 working capital financing requirements increased due to an increase in input prices of cotton and coal (Government of Pakistan, 2017-2018). Input prices of cotton have inverse relationship to productivity (Principles of Microeconomics, N. Gregory Mankiw, p. 702).

Large amount of loans are a burden on textile firms. Theoretically, loan able funds have inverse relationship to Interest rates. Economic slowdown caused sharp decline in products prices which further leads to increase in taking loans by textile firms, but that depends upon the rate of interest at which these loans are offered. Foreign Exchange Rates of foreign currency against local currency is positively related to exports, because theoretically, depreciation of rupee makes exports cheaper and appreciation makes them expensive (Principles of Microeconomics, N. Gregory Mankiw, p. 703).

International Export prices has a positive impact on exports of textile because high export) prices tends to increase producer surplus (Profit margin) (Latif \&Javid, 2016). More use of loans may results into the problem of financial distress that may lead to future bankruptcy. Hence, in order to avoid bankruptcy it is required to access from time to time the financial health of textile companies of Pakistan.

\subsection{Research Objectives 3}

1. An Analysis of Effect of Retained Earnings/Total Assets on financial distress of Pakistan's textile sector.

2. An Analysis of Effect of Sales/Total Assets on financial distress of Pakistan's textile sector.

3. An Analysis of Effect of Earnings before Tax/Equity on financial distress of Pakistan's textile sector. 
4. An Analysis of Effect of Cash Flow/Total Debt on financial distress of Pakistan's textile sector.

5. An Analysis of Effect of Working Capital/Total Debt on financial distress of Pakistan's textile sector.

6. An Analysis of Effect of Interest Rates on financial distress of Pakistan's textile sector.

7. An Analysis of Effect of Exchange Rates of foreign currency on financial distress of Pakistan's textile sector.

8. An Analysis of Effect of Cotton Prices on financial distress of Pakistan's textile sector.

9. An Analysis of Effect of Export Prices on financial distress of Pakistan's textile sector.

\section{Literature Review 1}

\subsection{Underpinning Theory: Cash Management Theory 2}

Cash management is concerned with distributing, cash forecasting, investing, and planning for steady administration of firm's business (Zimmerer, Thomas, Scarborough, Norman, \& Wilson, 2008). According to Watson and Head (2007), it is a theory that involves the effective use of available cash, maximizing interest on investments and decrease loss incidences that occurs due to lagging in transmission of money. Cash management is concerned with three issues; amount of liquid resources to hold, to determine how many liquid resources should be held as cash and as well as marketable securities and finally as a portfolio for marketable securities maturity.(Aziz \& Dar, 2006).

\subsection{Determinants of Financial Distress 3}

\subsubsection{Liquidity}

According to Keynes (1936), the reason for holding cash is for transaction, safeguarding and rumor purposes. These reasons can be enhanced to companies, as they require liquid assets for daily operations, to pay sudden debt, for gaining and development and other profitable investment opportunities. Short of liquidity may reflect a fall in asset prices, decline in external sources of finance and reduction in market base. Keige (1991), and Kiragu (1993), showed that liquidity, leverage, and debt service ratios are vital in predicting corporate financial failures.

2.2.2 Leverage

This ratio refers to the amount of debt or borrowing of a company to finance their operations. In 1994, Titman and Opler perceived a significant positive relationship between leverage and financial distress. Other studies which have similar conclusions are Keige (1991), Theodossiou, Kahya, Saidi, and Philippatos (1996) and Tan (2012) among others.

2.2.3 Profitability

According to Altman (1968) predicting corporate failure, profitability is an important financial ratio. Wang and Li (2007) study show that profitability has a positive significant influence on financial insolvency. To predict financial distress in Chinese listed companies they use a sample of four hundred and twenty four firms in which two hundred and twelve firms were bankrupt and others were non-bankrupt firms. Time period of the study was ranging from 1998-2005. According to Geng, Bose and Chen (2015) financial distress can be determined by seeing at the effect of firm's profitability.

\subsubsection{Firms Growth}

The main factors that show firm's growth are increase in earnings of the company and the sales volume. According to the study by Altman in 1984 that main indications of financial dilemma was a fall in sales volume. Whitaker (1999) determined that as the financial distress starts to occurs profitability of the firm drops below the level. 2.2.5 Management inefficiency

According to Oghe \& Prijcker (2008), business failures and bankruptcy occur due to low management skills and qualities, poor corporate policy and insufficient strategies making. Jahur and Quadir (2012) study found that in Bangladesh the major causes of financial distress found to be the poor management.

\subsection{Macroeconomic Factors 4}

As macroeconomic factors affects the whole economy but because of them only few companies become bankrupt and leave the economy. Majority of researchers emphasize on different macroeconomic factors that influence bankruptcy risks, these factors are:

$>\quad$ High interest rates
$>\quad$ Structural inequality in the economy
Difficulty in entering into capital market
Exchange rates instability
$>\quad$ Low research and development in the economy
$>\quad$ Scarcity of funds available for long term investments
$>\quad$ Declining environment for new investments
High inflation rates




\subsection{Empirical Studies5}

From last many decades, there are vigorous researches about financial distress predicting models, in spite of the fact that no consensus has been reached so far for best failure prediction model. Empirical studies about failure prediction models come from different dimensions. Some researchers at the same time focused on testing the analytical values of models, while others give suggestions to add variations that enhance the analytical power of these models to make comparisons as well as assessment so that to get their predictive value for mentioning the strengths and weaknesses. To avoid crisis, developing an effective early warning system in enterprises must be helpful for company operators to make relevant decisions, and also to improve the operating results and company's financial condition, and for the investors to make and avoid decisions or reduce investment losses when involve in crisis (Xu, 2015).

Macroeconomic environment in some cases has difficulties attached with it that go along with production decline and increase in cost of capital that started a crisis process in enterprises. Mass bankruptcies occur due to economic crisis as economic agents are closely related to each other. Market economy is a complex system of connections amongst diverse units that are connected by covenant relationship so there is a possibility of company's financial difficulties transferred to their partner businesses.

Contractual relationship strengthens the interconnections and interdependencies of market contributors, when insolvency and default of one of the parties and their obligations affect other party's financial condition and create economic consequences for its partner businesses. This is not only happening in economic crisis, some units may file for bankruptcy during economic expansion due to economic competition. In economic growth, there are factors that characterized by favorable external conditions, that makes it possible for severe production growth and vicious opposition. In this type of situation lot of firms are unable to compete due to inefficient management and lack of strategy development. Phases of economic decline and crisis make easy for the rebirth of the economy because of bankruptcy process. To clear the markets for more active economic business units, bankruptcy is an important instrument to eliminate unproductive business units.

Market mechanism involves in the incompetency of economic agents failure. Some factors create conditions, are a hurdle in sustainable economic development of a company includes competition, cyclical development, market insecurity and irregularity of information. Factors that become reasons behind bankruptcy have been widely studied in empirical literature, although we may not know what the difference between them is. According to Lvova O.A. reasons and factors of bankruptcy exists due to internal and external changing condition of a company's operating environment that creates negative impact when bankruptcy reasons happen (Lvova \& Peganova, 2014).

Factors related to bankruptcy include a disturbing event or movement that shows there will be a possible company's business failure in near future. All operations of business entities are affected by bankruptcy factors. Overall, micro and macroeconomic factors influence the results of firm's bankruptcy while in crisis.

Bankruptcy can also happen due to many other reasons that are different for other companies in the market. It may happen due to the combination of internal and external problems of companies. These factors are:

2.4.1 Operating reasons:

- High fixed assets depreciation can happen due to lack of modern technology

- $\quad$ Company cash flows managed inefficiently

- $\quad$ Capital turnover becomes slow due to high percentage of work in progress in current assets

- $\quad$ There will be a unbalanced growth of business in receivables against goods delivered but not paid, no payment against increased receivables for goods delivered, also there may be a violation of balanced growth rates

- $\quad$ High cost of goods sold due to inefficient use of operating resources

2. 4.2 Managerial reasons:

- No strategy developed for crisis management

- Imbalanced strategy to handle the situation that leads to wrong assessment of risks and making wrong decisions

- Strategy that leads to suggest large borrowings

- Audit control deficiency

2.4.3 Financial reasons:

- Large amount is invested in fixed assets, whereas working capital administered uneconomically

- High borrowing cost

- Negative financial leverage

- Financial risks miscalculation

- Ineffective budgeting system and financial strategy (Vorotnikova \& Pshipiy, 2015).

Exchange rates have direct effect on the company in probability of default. When exchange rates become 
high in market, this will result in expensive imports, exporting of goods become easier, and leads to few competitors in international market that resulted a decline in local companies. Understanding about the sensitivity of macroeconomic variations, vary with company. More the company is doing well; there will be less chances of probability of default due to macroeconomic factor changes (Qu, 2008).

Different researchers opinion have been carried out on the effectiveness of the models (Agarwal \& Toffler, 2008; Das, Paul, \& Atulya, 2009; Bauer \& Agarwal, 2014). According to them accounting based, market based and hazard model dominated in finance literature (Altman, Malgorzata, Erkki, \& Arto, 2014).

Financial ratios are important in evaluating any company's financial health in the market. Firstly, it is easy for management to classify possible risks that requires more attention (Siegel, 1981; Odom \& Sharda, 1990). Secondly, due to their help, investors evaluate the firm's financial health and lastly they are helpful for auditors in ongoing concern evaluation (Altman, 1982; Odom \& Sharda, 1990).

Advanced techniques and models were introduced with the passage of time to predict bankruptcy. Ratios before were only used to predict financial health of a company. However, corporate business sector later includes other factors that related to macroeconomics that also have more effects on the effectiveness of models used (Dyrberg, 2004; Lee, 2003; Grunert, Jens, Norden, L., \& Weber, 2005).

Fitzpatrick identified significant differences between financially healthy and distress businesses (Misankova, Maria, \& Bartosova, 2016; Valášková, Katarína, Švábová, \& urica, 2017).

Altman, Iwanicz-Drozdowska, Laitinen, and Suvas (2017) examined bankruptcy prediction using Z-score. Study was conducted on 28 European and 3 non-European country's companies to analyze Columbia, China and United States. Time period for the analysis was 2002-2010. Sample of the study was 2,602,563 active firms and 38,215 distress firms. According toresults Z-, score still the best model to predict bankruptcy with high accuracy rate in international context.

Azhar and Ramesh (2017) in their study demonstrates that majority companies in India are not financially sound by their health and it is the duty of these companies management on urgent basis that they should administer and reduce the financial difficulties facing these companies are facing. According to the study by Maina and Sakwa (2017), financial health of companies in Kenya demonstrates a critical financial situation and can be in danger zone.

Oniga (2016) study was based on classical prediction models applicability for Romanian insurance companies namely Altman Z-score, adjusted Altman Z" score, Springate and insolvency probability for emerging markets model. Secondary data was collected for 2011 to 2013. According to results Altman Z-score achieved high predictive results with 63 percent prediction rate, while other three models demonstrates prediction ratio lower than 16 percent. In their conclusion researchers propose other prediction models to be used that are appropriate to Romanian economy and insurance companies.

Durica and Adamko (2016) confirm MDA bankruptcy prediction models for enterprises in Slovakia.

Aleksanyan and Huiban (2016) in their study demonstrates that situation of bankruptcy occur due to firm's failure to survive in market competition, that creates other multiple harmful consequences on irregular basis like job losses, damage of firm's assets and productivity.

Bauer and Edrész (2016) built a Probit model for private Hungarian companies for the period ranging from 1996-2014. Main features of study was the addition of macroeconomic variables like GDP growth, cost of borrowing, rate of total bank loan volume and qualitative variables like company size, age, ownership structure, industry, exporter status.

Singh and Mishra (2016) study was based on the comparison of Altman, Ohlson and Zmijweski models in two different ways. First they applied original values and afterwards apply the re estimated values to compare. Sample for their study was consisted 208 Indian manufacturing firms of which 130 were bankrupt and 78 were non-bankrupt. Bankrupt firms were financially sick during the period 2006-2014. Singh and Mishra(2016), confirmed the results of Grice and Ingram, (2001) concerning about the stability of coefficients of model to be tested in the given period and were found to be sensitive during the period regarding Indian manufacturing firms. The original value of Altman was 62 percent that went high after re estimating coefficients and goes to $88.5 \%$ in Zmijewshki model the original coefficients value become 80 percent that changes to 77 percent after re-estimating the coefficients of the model. In Ohlson, model values of coefficients become $64 \%$ and changes to $90 \%$ after re estimation.

Sajjan (2016) examined financial health of manufacturing and non-manufacturing sector of India using two versions of Altman model (Z score, Z" score). Three companies were selected from each sector for the period of five years ranging from 2011-2016. According to results researcher concluded that most firms are in distress zone and may become bankrupt in near future and it should be the responsibility of the top management that they should maintain operational strategies to improve the resource management operational performance of these companies.

Kurschs, Sarapovas and Evilikas (2015), study relates to small and medium companies bankruptcy. For bankruptcy prediction models, they use different characteristics of small and medium companies. They examined small and medium company's different elements and their flexibility under economic crisis. According to them 
both external and internal factors are responsible for bankruptcy crisis of a company.

Gizem (2015) analyzed the financial health of 41 insurance companies operating in Turkey for the period 1998-2012. Models used in the study to predict bankruptcy were MDA, Logit, Bayesian regression and linear regression. According to the results, it was concluded that Bayesian regression becomes the best bankruptcy prediction model for Turkish insurance companies with a ratio of 90 percent. This model is also used to predict bankruptcy for 2013 as well.

Bemš, Starý, Macaš, Žegklitz, and Pošík(2015)proposed a new concept namely modified magic square that was used in macroeconomics among others in enterprise insolvency forecasting. Financial ratios were used to check the data for Czech companies. They proposed a model by comparing other models with different estimation techniques to obtain results that use logit model, artificial neural networks, evolutionary algorithms and Bayes classifiers. By adding value and giving the accuracy of model in comparison to other models, they present their results of financial condition along with the impact of explanatory variables graphically.

Shirinkina and Valiullina (2015) examined different empirical studies, categorize models of risk estimation, and pointed out six most regularly used coefficients. According to their study, explanatory variables were presented for above variables to examine but there was no explanation available for the accuracy of the model (Shirinkina \& Valiullina, 2015).

Stahlman (2015) developed a model for corporate bankruptcy prediction for manufacturing industry based on micro and small enterprises financial data from all over Europe.

Gundova (2015) and Sofrankova (2014) compare the results of prediction methods in a group of Slovak companies, prediction methods accuracy proof is evaluated by (Camska, 2016).

Kusumawardani (2015) study based on the analysis of BEI and examined companies that were delisted during 2009 to 2013. According to the results, Zmijewski followed by Springate and Altman model gives high accuracy in bankruptcy prediction rate that leads to delisting.

Celli (2015) examined a data of 102 Italian companies listed at Italian stock exchange for a period of 1995 2013 using Altman Z-score. From these 102 companies there were 51 companies were delisted and 51 were listed. According to his results, Altman Z-score can be applied in context to Italian firms for bankruptcy prediction.

Bal (2015) examined FMCG Company's financial health using Altman Z-score for the period 2011-2015. According to the study all companies of FMCG has good health and become successful except Godrej Company in 2014.

Gunathilaka (2014) study applied MDA to test Z score models of Altman and Springate. Time period of the study was 2008-2012, and the sample size was 82 listed firms from different sectors of Colombo Stock Exchange. According to the results of the study, solvency test does not deeply differentiate firms as solvent or insolvent. Altman and Springate Z-score models tests have almost same predictive accuracy comparing each other, while in immediate year prior to distress Altman Z-score established highclassification accuracy.

Mareike (2014) examined different models accuracy rate of bankruptcy prediction for Germany and Belgium listed companies by using Altman, Ohlson, and Zmijewski models. Study sample covered a period of three years from 2008-2013 with a sample size of 5786 firms in which 5646 were active firms and 140 were distress in Belgium, and also a sample of 1453 firms in Germany in which 1432 were active and 21 were bankrupted. All prediction models predict different results in both countries, as the accuracy of German listed companies are lower than Belgium listed companies. Accuracy rates of bankruptcy prediction in Belgian companies for Altman, Ohlson and Zmijewski are 68.3 percent, 68 percent and 67.9 percent respectively, while German company's bankruptcy accuracy rates are $52 \%, 53 \%$ and $52 \%$ respectively. In additionOhlson model found to the best model used in predicting bankruptcy.

Bozkurt (2014) examined different models that best explain risk factor for bankruptcy prediction of firms in BIST. 127.0 ThousandTransactionswere observed during the period 2005 to 2011 on the sample of 168 firms that were listed on BIST. Total of eight different bankruptcy models were used to evaluate the values using normal distribution to predict bankruptcy. According to the results, systematic risk becomes high due to high level of bankruptcy risk and also all prediction models like Altman, Springate, and Ohlson are all effective models to predict bankruptcy in BIST.

Civan and Day1 (2014) examined the financial health of companies that are related to Zonguldak Hospitals Union for the period 2008 to 2012. Models tested were Altman Z-score and Artificial Neural Networks (ANN). According to results of Altman Z-score 4 percent has a chance that they would become 27 percent unsuccessful firms has a 95 percent chance that would fail within one year. Additionally, 69 percent firms were classified as non-bankrupt and $31 \%$ were classified as bankrupt. ANNs on the other hand gives 85 percent success rate. Bankrupted firms were estimated incorrectly for 2 years and correctly estimated for 27 periods. To categorize the models it was evaluated that all the companies become successful in estimation.

Karamzadeh (2013) study consists on a sample of 90 firms listed at Tehran stock exchange for the period 2007-2010. According to his results, Altman gives higher accuracy rate than Ohlson model as $75 \%$ for first year, 65 percent for second year and 50 percent in third year. Prihanthini and Sari (2013), examined food and beverages 
companies listed at BEI and concluded that Grover model gives highest accuracy in predicting bankruptcy followed by Springate, Zmijewski and Altman models.

Grice and Dugan (2003) examined Ohlson and Zmijewski models. They re-estimate the coefficients of model and compare them with original values. Data was taken from Compustat database of North American and Canadian companies. Sample of 1024 companies in which 183 were failed and 841 were non-failed for Zmijewski model and sample of 1,043 were taken in which 154 were failed and 889 were non-failed companies for Ohlson model. According to their results Zmijewski model values were not stable in the given period, were changing, and can say that they are not sensitive to industry classification.

Shumway (2001) used hazard prediction model and found that market size, historical stock returns and individual returns are related to bankruptcy. To predict bankruptcy he took variables from accounting ratios and market determined variables. Atiya (2001) study stated that the combination of financial ratios and bankruptcy indicators, gave better important development in prediction accuracy. Prediction model they gave resulted as $81.46 \%$ to 85.5 percent accuracy forecasted for three ahead years.

\section{Research Design and Research Methodology 1}

This research project focused on Textile sector of Pakistan as textile is one of the major contributor sector of Pakistan economy. The data employed is derived from Balance Sheet Analysis of PSX listed firms, covered a sample of one hundred and twenty firms taken from APTMA to check the financial distress status of firms using Fulmer model for a period ranging from 2012-2018. After calculating values, data will be further analyze using SPSS. Regression analysis, ANOVA and Correlation will be done on the data. Benchmark of the study for value of $\mathrm{H}$ will be if $\mathrm{H}<0$, then company will be categorized as a bankrupt.

\subsection{Type of Research 2}

Research technique used in this study is quantitative research. It is a type of research in which numeric databases are used in order to derive meanings from numbers (Aliaga\& Gunderson, 2004). According to Saunders, Lewis, and Thornhill (2009) quantitative research is mostly used as a synonym for any kind of data collection technique.

\subsection{Sample Size 3}

The data employed is derived from Balance Sheet Analysis of PSX listed firms, covered a sample of one hundred and twenty firms taken from APTMA to check the financial distress status of firms using Fulmer model for a period ranging from 2012-2018.

\subsection{Data Collection Method 4}

Secondary data was employed in the study that derived from balance sheet analysis of firms for a period of seven years ranging from 2012-2018.

\subsection{Data Collection Method 5}

After calculating values, data will be further analyzed using SPSS. Regression analysis, ANOVA and Correlation will be done on the data. Benchmark of the study for value of $\mathrm{H}$ will be if $\mathrm{H}<0$, then company will be categorized as a bankrupt. The formula to calculate $H$ value is:

$\mathrm{H}=5.528(\mathrm{XI})+\mathbf{0 . 2 1 2}(\mathrm{X} 2)+0.073(\mathrm{X3})+1.270(\mathrm{X} 4)-0.120(\mathrm{X5})+\mathbf{2 . 3 3 5}(\mathrm{X6})+0.575(\mathrm{X} 7)+1.083(\mathrm{X8})+$ 0.894 (X9) - 6.075 


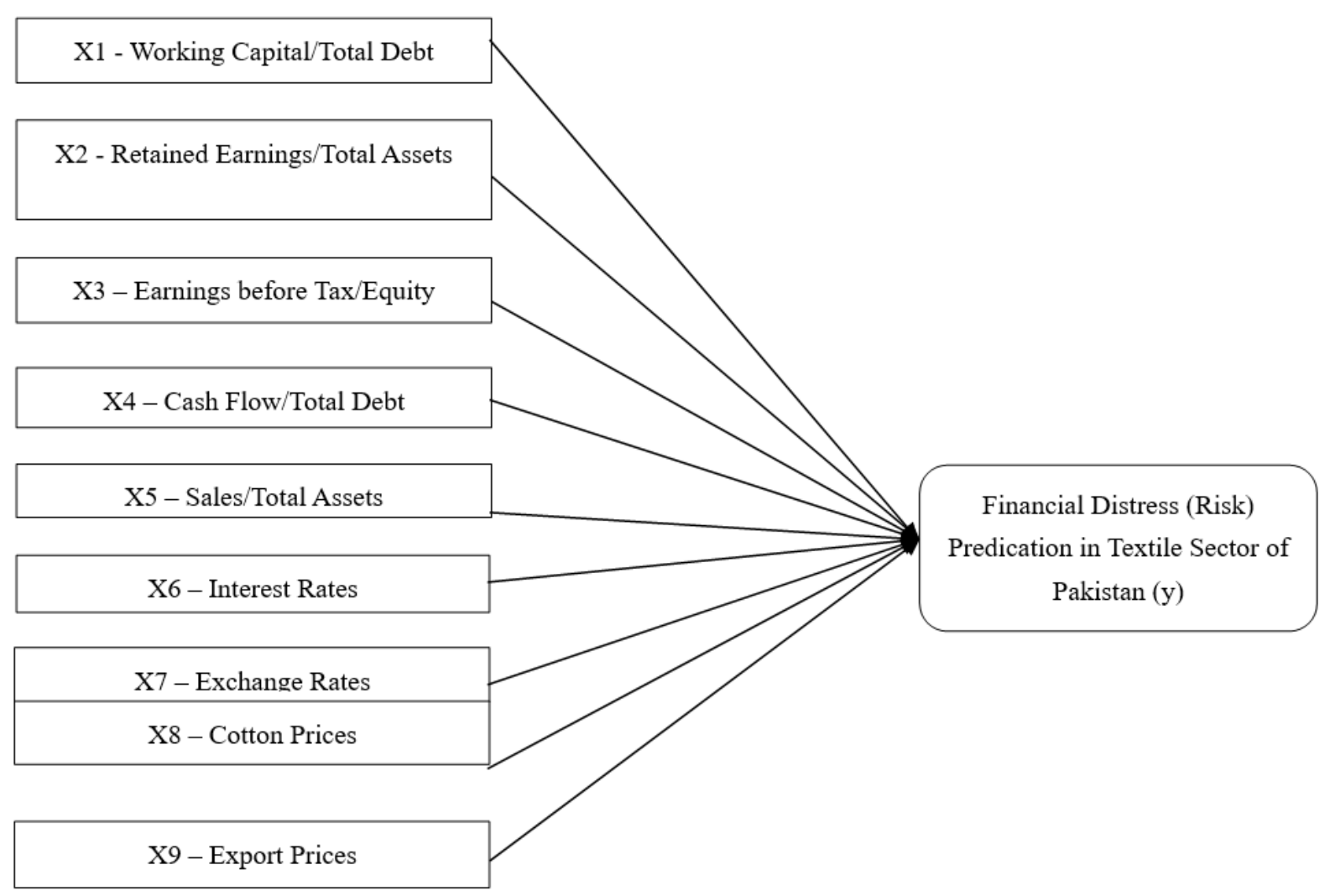

Figure 1. Research Model

Visual Illustration of theoretical model

\subsection{Limitation of Study 6}

1. The assumptions of model are the limitations of study.

2. Study data ranges from 2012 to 2018 , as there was unavailability of data before 2012 and after 2018 , due to this problem period of 2012-2018 was selected.

3. Researcher took four macroeconomic variables, because they would have crossed the restrained of the thesis of mind

Sample size of 120 firms becomes the limitation, as most of companies did not publish their financial data.

\section{Findings (or Results) 1}

\subsection{Test of Significance 2}

To test the significance following tests were done: coefficient of determination $\left(\mathrm{R}^{2}\right)$, ANOVA and coefficient of correlation (r). $\mathrm{R}^{2}$ measure the dependent variable deviation due to predictor variables. ANOVA test was conducted to test whether there are significant variances among variables. And lastly correlation coefficient (r) was used to determine the strength and direction of linear relationship between dependent variable. Financial distress prediction in textile sector of Pakistan (y) and independent variables X1(working capital/total debt), X2(Retained earnings/total assets), X3(earnings before tax/ equity), X4(cash flow/total debt), X5(sales/total assets), X6(interest rates), $\mathrm{X} 7$ (exchange rates), $\mathrm{X} 8$ (cotton prices) and $\mathrm{X} 9$ (export prices). 
4.2 Descriptive Statistics 3

Table 1. Descriptive Statistics

\begin{tabular}{|l|l|l|l|l|l|}
\hline & $\mathrm{N}$ & Minimum & Maximum & Mean & $\begin{array}{l}\text { Std. } \\
\text { Deviation }\end{array}$ \\
\hline Working Capital/Total debt & 840 & -.97 & 316.27 & 1.2524 & 15.65784 \\
Retained Earnings/Total Assets & 840 & -8.46 & 6.39 & .0860 & .87673 \\
Earnings before Tax/Equity & 840 & -32.34 & 11.03 & -.2780 & 1.86736 \\
Cash Flow/Total Debt & 840 & -50.78 & 171.19 & .4977 & 8.60732 \\
Sales/Total Assets & 840 & .00 & 10.56 & 1.0019 & .83826 \\
Interest Rates & 840 & 7.07 & 70.70 & 9.2143 & 2.99860 \\
Exchange Rates & 840 & 8.2400 & 121.4386 & 103.819189 & 10.2219875 \\
Cotton Rates & 840 & 620.58 & 64343.00 & 6039.0170 & 2092.47170 \\
Export Prices & 840 & 12.23 & 13.85 & 13.4460 & .20543 \\
Financial Distress Prediction in Textile Sector of & 840 & 5596.77 & 12159.20 & 6575.9895 & 622.55892 \\
Pakistan (y) & & & & & \\
Valid N (list wise) & 840 & & & & \\
\hline
\end{tabular}

High standard deviation means data is spread over a large number of values than their means. While low standard deviation means data are clustered closely around the mean. The coefficient of variation is high when $\mathrm{CV}>=1$, and it becomes low when $\mathrm{CV}<1$.

Table 2. Pearson Correlation Results

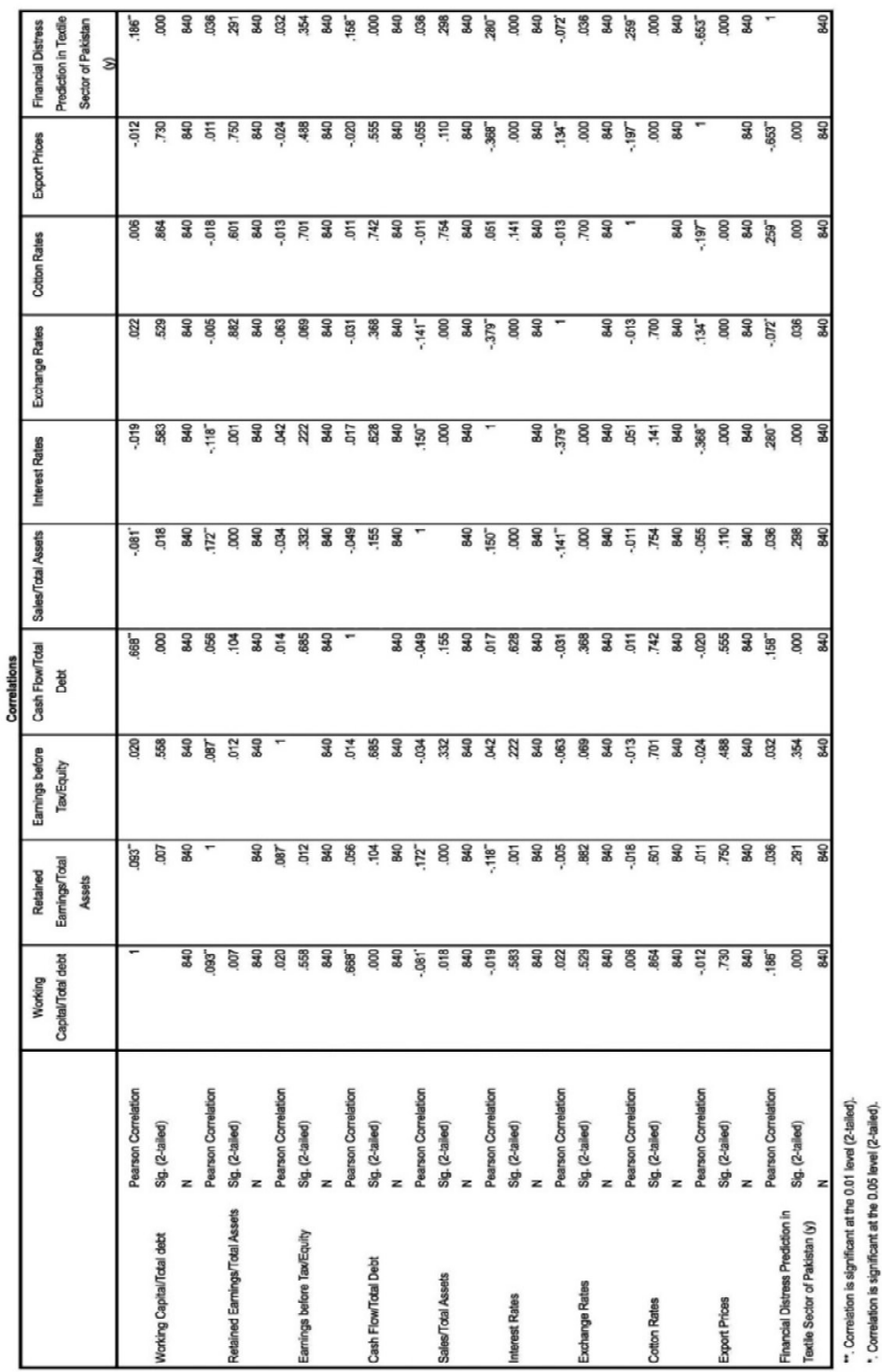

This study has used Pearson Correlation. The correlation table shows the interdependency of the variables. 
Correlation matrix shows that variables value fall at +1 . Value greater than zero shows a positive association between variables of study. Value of +1 shows that all data points are included on line of best fit and have a positive linear relationship.

Table 3. Coefficients

\begin{tabular}{|c|c|c|c|c|c|c|}
\hline \multirow{2}{*}{\multicolumn{2}{|c|}{ Model }} & \multicolumn{2}{|c|}{ Unstandardized Coefficients } & \multirow{2}{*}{$\begin{array}{l}\text { Standardized } \\
\text { Coefficients } \\
\text { Beta }\end{array}$} & \multirow[t]{2}{*}{$\mathrm{t}$} & \multirow[t]{2}{*}{ Sig. } \\
\hline & & B & Std. Error & & & \\
\hline \multirow{10}{*}{1} & (Constant) & 30489.299 & 1163.949 & & 26.195 & .000 \\
\hline & Working Capital/Total debt & 5.750 & 1.344 & .145 & 4.279 & .000 \\
\hline & $\begin{array}{l}\text { Retained Earnings/Total } \\
\text { Assets }\end{array}$ & 25.361 & 18.436 & .036 & 1.376 & .169 \\
\hline & Earnings before Tax/Equity & 4.118 & 8.399 & .012 & .490 & .624 \\
\hline & Cash Flow/Total Debt & 3.326 & 2.432 & .046 & 1.367 & .172 \\
\hline & Sales/Total Assets & 5.339 & 19.325 & .007 & .276 & .782 \\
\hline & Interest Rates & 14.616 & 6.081 & .070 & 2.403 & .016 \\
\hline & Exchange Rates & 2.269 & 1.657 & .037 & 1.370 & .171 \\
\hline & Cotton Rates & .041 & .008 & .137 & 5.363 & .000 \\
\hline & Export Prices & -1825.424 & 83.046 & -.602 & -21.981 & .000 \\
\hline
\end{tabular}

a. Dependent Variable: Financial Distress Prediction in Textile Sector of Pakistan (y)

Beta values indicate the rate of changing in variable. Cotton prices and working capital to total debt have a higher rate of change than other variables. It shows the efficiency of the variables. In the output above we can see an increase in cotton prices by a unit leads to an increase in $\mathrm{H}$ by 5.363, increase in working capital to total debt by a unit leads to an increase in $\mathrm{H}$ to 4.279 . Increase in interest rates by a unit led to increase in $\mathrm{H}$ by 2.403 and increase in export prices by a unit leads to an increase in $\mathrm{H}$ by -21.981 .

The results shows that $\mathrm{P}$ value of working capital/total debt, interest rates, cotton rates, and exports prices are found significant. In addition, the value of RE/TA, EBT/Equity, CF/TD, S/TA and exchanges rates are found insignificant.

Table 4. Model Summary

\begin{tabular}{|l|l|l|l|l|l|}
\hline Model & R & R Square & Adjusted R Square & Std. Error of the Estimate & Durbin-Watson \\
\hline 1 & $.694^{\mathrm{a}}$ & .482 & .476 & 450.47055 & 2.380 \\
\hline
\end{tabular}

a. Predictors: (Constant), Export Prices, Retained Earnings/Total Assets, Cash Flow/Total Debt, Earnings before Tax/Equity, Exchange Rates, Cotton Rates, Sales/Total Assets, Interest Rates, Working Capital/Total debt b. Dependent Variable: Financial Distress Prediction in Textile Sector of Pakistan (y)

This table represents the summary of regression statistics. $\mathrm{R}$ is the correlation coefficient, and $\mathrm{R}^{2}$ is the coefficient of determination, which shows how much variation in dependent variable is occur due to independent variables. In this study $\mathrm{R}$ Square $=.482$, which means $48.2 \%$ of change is explained by the predictor variables $(\mathrm{X} 1$, X2, X3 ...X9) and $51.8 \%$ by something else. The Adjusted R Square value of 0.476 explains that adjustment in the number of predictor variables explain 47 percent of the variations. Durbin-Watson value is 2.380 that mean that there is no autocorrelation presence in the data and values lies between 1.5 to 2.5 is relatively normal values. Table 5. Anova

\begin{tabular}{|l|l|l|l|l|l|}
\hline Model & Sum of Squares & df & Mean Square & F & Sig. \\
\hline Regression & 156752609.097 & 9 & 17416956.566 & 85.830 & $.000^{\mathrm{b}}$ \\
1 Residual & 168426682.101 & 830 & 202923.713 & & \\
Total & 325179291.198 & 839 & & & \\
\hline
\end{tabular}

a. Dependent Variable: Financial Distress Prediction in Textile Sector of Pakistan (y)

b. Predictors: (Constant), Export Prices, Retained Earnings/Total Assets, Cash Flow/Total Debt, Earnings before Tax/Equity, Exchange Rates, Cotton Rates, Sales/Total Assets, Interest Rates, Working Capital/Total debt

A variable is statistically significant if significant value is 0.05 , while it is less significant if value is above 0.05 . In these results, null hypothesis states that mean hardness values of 10 variables are equal as $p$-value is 0 , which is less than significance level value $\mathrm{p}=0.05$ and $\mathrm{F}$ value is 85.830 , so we reject null hypothesis and conclude that some variables in the study have different means. 
Table 6. Residual Statistics

\begin{tabular}{|l|l|l|l|l|l|}
\hline & Minimum & Maximum & Mean & Std. Deviation & $\mathrm{N}$ \\
\hline Predicted Value & 5563.7974 & 9077.6904 & 6575.9895 & 432.24145 & 840 \\
Residual & -2081.91943 & 6359.79248 & .00000 & 448.04792 & 840 \\
Std. Predicted Value & -2.342 & 5.788 & .000 & 1.000 & 840 \\
Std. Residual & -4.622 & 14.118 & .000 & .995 & 840 \\
\hline
\end{tabular}

a. Dependent Variable: Financial Distress Prediction in Textile Sector of Pakistan (y)

\section{Conclusion 1}

By summarizing, the debate it is said that as business expand in modern global economy, cutthroat competition also becomes a reality. It becomes more important for businesses not only to diversify but also to break through with their respective products on different markets through cost cutting techniques and technologies. For survival and carrying on business activities, an organization should have to manage their finances on priority matters that need utmost care and attention. Therefore, company's financial health and position can be monitored through their financial statement that tells how good company's operational competence and strong financial health is. Financial distress comprises of numerous situations where a company has to face some form of financial difficulty.

Pakistan textile sector have severe challenges from China, India and other Asian countries who from last many years established a solid base for their value added textile. Regardless of investing Billions of dollars in upgrading textile technology our textile sector is still facing a critical situation in global competition. During JulyFebruary fiscal year 2018 there was an immense increase in private sector loans especially in manufacturing sector which received a share of almost 59.8 percent or (PKR 206.3 Billion), textile share was 35.8 percent (PKR 123.5 Billion), therefore during fiscal year 2017 working capital financing requirements increased due to increase in input prices of cotton and coal. Large amount of loans are a burden on textile firms. More use of loans may results into the problem of financial distress that may lead to future bankruptcy.

This research project focused on Textile sector of Pakistan. Data employed was derived from annual reports of firms, sample size was one hundred and twenty firms taken from APTMA to check the financial distress status of firms using Fulmer model for a period 2012-2018. After calculating values, results of regression analysis, ANOVA and correlation coefficient revealed that working capital/total debt, interest rates, cotton prices and export prices were found significant. This study concluded that RE/TA, EBT/Equity, CF/TD, S/TA and exchanges rates have negative and insignificant relation with financial distress prediction.

\subsection{Future Direction/Recommendations 2}

1. Fulmer model is not been widely used in Pakistan economy context. This research thesis has established that Fulmer model should be used not only in manufacturing sector but also extended to other sectors of economy. 2. Fulmer model should be investigated with other models and more variables from financial ratios and micro and macroeconomic variables.

3. More sectors of economy should be investigated with the help of Fulmer model.

4. Financial distress models would be helpful for policy makers and investors of the firms to estimate their capacity against the downturn. Government would provide key inputs that would be necessary for policy intrusions. 5. This study would be helpful for board of directors, financial managers of firm's inclining towards distress towards bankruptcy.

6. Regulators should have to make effective measures and raised the red flag when in their mind when sensed the firm is going towards distress.

7. Future investors should have to understand and abolish the potholes towards the sustainable profitability of their investments.

8. This study can serve as benchmark for future researchers.

\section{References}

Agarwal, V., \& Taffler, R. J. (2005). Twenty-five years of z-scores in the UK: Do they really work? 1-36.

Aleksanyan, Lilia, \& Huiban, J.-P. (2016). Economic and financial determinants of firm bankruptcy: Evidence from the French food industry. Review of Agricultural, Food and Environmental Studies, 97, 89-108.

Altman, E. I. (1968). Financial Ratios, discriminant analysis and the prediction of corporate bankruptcy. The Journal of Finance, 23(4), 589-609

Altman, E. I. (1993). Corporate financial distress and bankruptcy. A complete guide to predicting and avoiding distress. Second Edition. USA, John Rileyand Sons Inc

Altman, E. I., Iwanicz-Drozdowska, M., Laitinen, E. K., \& Suvas, A. (2014). Distressed firm and bankruptcy prediction in an international context: A review and empirical analysis of Altman's Z-Score model. doi:https://dx.doi.org/10.1111/jifm.12053 
Altman, E., Iwanicz-Drozdowska, M., Laitinen, E., \& Suvas, A. (2017). Financial distress prediction in an international context: A review and empirical analysis of Altman's Z-Score model. Journal of International Financial Managament \& Accounting, 28, 131-71.

Arnold, G. (2007). Model distress and recovery predictions. Financial Analysis Journal.

Bal, G. (2015). Prediction of financial distress using Altman Z-score: A study od select FMCG companies. Indian Journal of Applied Research

Bauer, P., \& Edrész, M. (2016). Modelling bankruptcy using hungarian firm-level data MNB occasional papers 122. Budapest: Magyar nemzeti bank.

Beaver, W. H. (1966). Financial ratios as predictors of failure. Journal of Accounting Research, 4, 71-111. doi: $10.2307 / 2490171$

Bemš, J., Starý, O., Macaš, M., Žegklitz, J., \& Pošík, P. (2015). Innovative default prediction appraoch. Expert Systems with Applications, 42, 6277-85

Bozkurt, İ. (2014). İflas Olasılığı İle Sistematik Risk İlişkisinin İncelenmesi ve Etkin İflas Göstergesi Modellerinin Tespiti: BİST'de Ampirik Bir Uygulama. Süleyman Demirel Üniversitesi İktisadi ve İdari Bilimler Fakültesi Dergisi, 19(4), 127-142.

Camska, D. (2016). Accuracy of models predicting corporate bankruptcy in a selected industry branch. Journal of Economics, 64(4), 353-366.

Celli, M. (2015). Can Z-Score model predict listed companies' failure in Italy? An empirical test. International Journal of Business and Management, 10(3), 57-66. doi:http://dx.doi.org/10.5539/ijbm.v10n3p57

Civan, M., \& Dayı, F. (2014). Altman Z Skoru ve Yapay Sinir Ağları Modeli İle Sağlık İşletmelerinde Finansal Başarısızlık Tahmini. Akademik Bakış Dergisi, 41.

Dr. M. Velavan, M.Mumtha, D. V., Pavithra, C., Pavisathya, G., \& Padmaja, R. (2018). A comparative financial health analysis of paper mills in Tamil Nadu in India- A study by using 'Z' score model. International Journal of Pure and Applied Mathematics, 119(10), 1565-1579

Durica, M., \& Adamko, P. (2016). Verification of MDA bankruptcy prediction models for enterprises in Slovak Republic. In T. Loster \& T. Pavelka (Eds.). Proceedings of the 10th international days of statistics and economics, Praha: Melandrium, 400-407.

Dyrberg, A. (2004). Firms in Financial Distress: An Exploratory Analysis. Danmarks NationalbankWorking Papers, Copenhagen: Danmarks Nationalbank., 17.

Fulmer, J. G., Moon, J., James, E., Gavin, T., Erwin, A., \& Michael, J. (1984). A bankruptcy classification model for small firms. Journal of Commercial Bank Lending , 25-37.

Geng, R., Bose, I., \& Chen, X. (2015). Prediction of financial distress: An empirical study of listed Chinese companies using data mining. European Journal of Operational Research. doi:http://dx.doi.org/10.1016/j.ejor.2014.08.016

Gizem, O. (2015). An early warning model for Turkish insurance companies.

Government of Pakistan. (2017-2018). Pakistan Economic Survey. Ministry of Finance. Retrieved from http://www.finance.gov.pk

Grice, J., \& Dugan, T. (2003). Re-estimations of the Zmijewski and Ohlson bankruptcy prediction models. Advances in Accounting, 20, 77-93.

Gunathilaka, C. (2014). Financial distress prediction: A comparative study of solvency test and Z-score models with reference to Sri Lanka. The IUP Journal of Financial Risk Management, 11(3), 40-50

Gundova, P. (2015). Verification of the selected prediction methods in Slovak. Acta academica karviniensia, 4, 26-39

Harlan, \& Marjorie. (2002). Predicting corporate financial distress: Reflections on choice - based sample bias. JOURNAL OF ECONOMICS AND FINANCE, 26(2).

Karamzadeh, M. (2013). Application and comparison of Altman and Ohlson models to predict bankruptcy of companies. Research Journal of Applied Sciences, Engineering and, Technology, 5(6), 2007-2011

Karas, M., \& Reznakova, M. (2017). Predicting the Bankruptcy of Construction Companies: A CART-Based Model. Inzinerine Ekonomika-Engineering Economics, 28(2), 145-154.

Kiragu, M. (1993). The prediction of corporate failure using price adjusted accounting data. Nairobi: University of Nairobi.

Kurschs, R., sarapovas, T., \& cvilikas, A. (2015). The criteria to identify company's crisis in SME sector. InzinerineEkonomika Engineering Economics, 26(2), 152-158.

Kusumawardani. (2015). Analisis ketepatan model Altman, Springate dan Zmijewski dalam memprediksi perusahaanyang delisting di Bursa efek Indonesia periode 2009-2013.

Lvova, O., \& Peganova, O. (2014). Factors and reasons of companies bankruptcy in present economic conditions. Public Administration: Electronic Journal , 65-68.

Lvova, O., \& Peganova, O. (2014). Factors and reasons of companies bankruptcy in present economic conditions. Public Administration: Electronic Journal , 65-68. 
Maina, F., \& Sakwa, M. (2017). Understanding financial distress among listed firms in stock exchange: A quantitative approach using $\mathrm{Z}$ score multi-discriminant financial analysis model. Jomo Kenyatta University of Agriculture and Technology, Nairobi, Kenya

Mankiw, N. G. (2008). Principles of Microeconomics. 5th Edition.

Mareike, K. (2014). Comparison of accounting-based bankruptcy prediction models of Altman (1968), Ohlson (1980), and Zmijewski (1984) to German and Belgian listed companies during 2008 - 2013.

Misankova, Maria, \& Bartosova, V. (2016). Comparison of selected statistical methods for the prediction of bankruptcy. Paper presented at 10th International Days of Statistics and Economics Prague, Czech Republic 8-10. Available online: https://msed.vse.cz/msed 2016/article/205-Misankova-, 1260-69.

Odom, M., \& Sharda, R. (1990). A neural network model for bankruptcy prediction. In international joint conference on neural networks. 163-8.

Oniga, A. (2016). Classic Insolvency Prediction Models Tested On Romanian Insurance Companies. European Scientific Journal, 12(13)

Qu, Y. (2008). Macroeconomic factors and probability of default. European Journal of Economics, Finance and Administrative Sciences , 192-215

Sajjan, R. (2016). Predicting bankruptcy of selected firms by applying Altman's Z-score model. International Journal of Research Granthaalayah, 4(4)

Shumway, T. (2001). Forecasting bankruptcy more accurately: A simple hazard model. Journal of Business, 74(1), 101-24.

Siegel, G. J. (1981). Warning signs of impending business failure and means to counteract such prospective failure. The National Public Accountant, 24, 9-13

Singh, B., \& Mishra, A. (2016). Re-estimation and comparisons of alternative accounting based bankruptcy prediction models for Indian companies. Financial Innovation, 2(6), 1-28 